\title{
The Influence of Cultivation Method on Crop Production of Bitter Gourd (Momordica charantia L.)
}

\author{
Attila KESERÜ ${ }^{1}$, Erzsébet BUTA ${ }^{1}$, Orsolya BORSAI ${ }^{1}$, Cornel NEGRUȘIER ${ }^{1}$ and Dănuț MĂNIUȚIU ${ }^{1 *}$ \\ ${ }^{1}$ Department of Horticulture and Landscaping. University of Agricultural Sciences and Veterinary \\ Medicine, 3-5Mănăștur Street, 400372, Cluj-Napoca, Romania \\ *)Corresponding author, e-mail: dan_maniutiu@yahoo.com
}

BulletinUASVM Horticulture 73(2) / 2016

Print ISSN 1843-5254, Electronic ISSN 1843-5394

DOI:10.15835/buasvmcn-hort:12240

\begin{abstract}
Momordica charantia L. (bitter gourd or bitter melon) has been used in Asian traditional medicines for a long time, but in our country is less know. However the leaves, fruits and seeds can be used in many ways. Encapsulated products are valued for regulating triglyceride or cholesterol. In Asia (China, Japan and India), the fruits are used for diet of diabetic people and for curing people in natural medicine. In the recent time the Momordica extracts are used to inhibit cancer cells. Due to these considerations researches were set up at UASMV Cluj - Napoca to find the best way of cultivation to obtain high yield and quality fruits. The results concerning the influence of cultivation method on crop production of bitter gourd show that the higher early production $(0.72 \mathrm{~kg} / \mathrm{plant}$, respectively 0.93 $\mathrm{kg} / \mathrm{sm})$ was registered if the cultivation way was on two branches. The lowest crop production $(0.53 \mathrm{~kg} / \mathrm{plant}$, respectively $0.69 \mathrm{~kg} / \mathrm{mp}$ ) was obtained in case of cultivation on the main stem. The cultivation method on two branches generates differences of $0.19 \mathrm{~kg} / \mathrm{plant}$ and $0.24 \mathrm{~kg} / \mathrm{mp}$. This cultivation method generates the higher early production.
\end{abstract}

Keywords: bitter melon, cultivation technology, early production

\section{Introduction}

Bitter gourd (Momordica charantia L.) is a well known vegetable in Asian countries. The fruit of Momordica is popular in traditional medicine, in diet of diabetic people and it's commonly used in cooking (Kumar et al., 2010; Joseph and Jini, 2013). In the recent time, bitter gourd is used for its valuable chemical compounds (Fohs et al., 2014) to cure many human diseases, especially to treat some kind of cancer. Ray et al. (2010) and Shobha et al. (2015) demonstrate the cytotoxic activity of Momordica extract in breast and cervix cancer. The results were significant and shown that the Momordica extract can inhibit breast cancer cell growth and development. Also, Momordica fruits can be used as a dietary supplement for prevention of breast cancer.

In Romania, few years ago, Momordica was completely unknown. But today, the fruits are used in various diets and the leaves are utilized for tea preparation due to the high antioxidant properties.

\section{Aims and objectives}

The high interest for this vegetable and the demand on the Romanian market determined us to study the cultivation technology of Momordica. This study represents a possibility to grow Momordica in Transilvanian Plateau and to establish the best cultivation method for this vegetable.

\section{Materials and methods}

Biological material was represented by 'Enaja' a new cultivar of Momordica charantia L. The seeds of this cultivar were bought from Oradea from a private farm. The experiments were carried out in 2015 in a greenhouse belonging to UASMV Cluj - Napoca. As an experimental factor a different 
Tab. 1. The influence of cultivation ways on early production $(\mathrm{kg} / \mathrm{plant}$ and $\mathrm{kg} / \mathrm{mp})$ of Momordica

\begin{tabular}{cccc}
\hline Symbol & Cultivation ways & Early production $(\mathrm{kg} /$ plant $)$ & Early production $(\mathrm{kg} / \mathrm{mp})$ \\
\hline V1 & One branch & $0,60^{\mathrm{b}}$ & $0,77^{\mathrm{b}}$ \\
\hline V2 & Two branches & $0,72^{\mathrm{a}}$ & $0,93^{\mathrm{a}}$ \\
\hline V3 & Main stem & $0,53^{\mathrm{c}}$ & $0,69^{\mathrm{c}}$ \\
\hline & LSD 5\% & 0,04 & 0,02
\end{tabular}

Tab. 2. The unilateral influence of cultivation method on early production of bitter gourd

\begin{tabular}{|c|c|c|c|c|c|c|}
\hline \multirow{2}{*}{ Cultivation ways } & \multicolumn{2}{|c|}{ Early production } & \multicolumn{2}{|c|}{ Early production } & \multirow{2}{*}{$\begin{array}{c} \pm \mathrm{D} \\
\mathrm{kg} / \text { plant }\end{array}$} & \multirow{2}{*}{$\begin{array}{c} \pm \mathrm{D} \\
\mathrm{kg} / \mathrm{mp}\end{array}$} \\
\hline & $\mathrm{kg} /$ plant & $\%$ & $\mathrm{~kg} / \mathrm{mp}$ & $\%$ & & \\
\hline One branch - V1 & 0,60 & 114,6 & 0,77 & 111,6 & $0,07^{* * *}$ & $0,08^{(* * *)}$ \\
\hline Two branches - V2 & 0,72 & 136,1 & 0,93 & 134,3 & $0,19^{* * *}$ & $0,24^{* * *}$ \\
\hline Main stem - V3 (control) & 0,53 & 100,0 & 0,69 & 100,0 & 0,00 & 0,00 \\
\hline LSD 5\% & & & & & 0,02 & 0,03 \\
\hline LSD p $1 \%$ & & & & & 0,03 & 0,05 \\
\hline LSD p $0,1 \%$ & & & & & 0,05 & 0,09 \\
\hline
\end{tabular}

cultivation method was used (one branch, two branches and main stem). The harvest of the early production took place in 24.08.2015. Obtained results were statistically interpreted using Duncan test.

\section{Results and discussion}

As the results of Table 1 show the higher early production $(0.72 \mathrm{~kg} /$ plant, respectively $0.93 \mathrm{~kg} /$ $\mathrm{sm})$ was registered if the cultivation way applied is on two branches. The lowest crop production $(0.53 \mathrm{~kg} /$ plant, respectively $0.69 \mathrm{~kg} / \mathrm{mp})$ was registered in case of cultivation on the main stem.

Data of Table 2 present that the cultivation method on two branches generate differences of $0.19 \mathrm{~kg} / \mathrm{plant}$ and $0.24 \mathrm{~kg} / \mathrm{mp}$. The differences between cultivation methods were very significant and statistically assured as demonstrated by Fohs et al. (2014).

\section{Conclusions}

In the current experiment the best cultivation method for Momordica charantia L. was on two branches. This method generates the higher early production. The obtained result shows the possi- bility to grow Momordica charantia in Transilvania.

\section{REFERENCES}

1. Fohs A, Krejpcio Z, Król E, Rong X and Hołubowicz R (2014). The Effect of Cultivation Ways on Selected Morphological Characters of Bitter Gourd (Momordica charantia L.) Transplants and Plants, Fruit Yield and Chemical Content. Bulletin UASVM Horticulture 71(1):38-42.

2. Joseph B and Jini D (2013). Antidiabetic effects of Momordica charantia (bitter melon) and its medicinal potency. Asian Pac J Trop Dis. 3(2): 93-102.

3. Kumar SD, Vamshi SK, Yogeswaran P, Harani A, Sudhakar K, Sudha P and Banji D (2010). A medicinal potency of Momordica charantia. International Journal of Pharmaceutical Sciences Review and Research 1(2):95100.

4. Ray RB, Raychoudhuri A, Steele R, Nerurkar P (2010). Bitter melon (Momordica charantia) extract inhibits breast cancer cell proliferation by modulating cell cycle regulatory genes and promotes apoptosis. Cancer Res. 70(5):1925-1931.

5. Shobha CR, Vishwanath P, Suma MN, Prashant A, Rangaswamy C, Gowdappa BH (2015). In vitro anti-cancer activity of ethanolic extract of Momordica charantia on cervical and breast cancer cell lines. Int J Health Allied Sci 4:210-7. 